\title{
Analysis on the Cultivation Path of Contemporary College Students' Ecological Civilization Education
}

\author{
Zhang Hong \\ China Jiliang University
}

\begin{abstract}
Cultivating the educational quality of contemporary college students' ecological civilization is of great significance to promoting the construction of "beautiful China" and realizing the great rejuvenation of the Chinese nation. At present, the education of ecological civilization of college students in China has made great progress, but there are still problems in the lack of training ability of colleges and universities, the lack of professionalism of teachers and the weak consciousness of students. Therefore, this paper conducts a research from four aspects, including education subject, educational object, educational mediator and educational ring body. It proposes the cultivation path of contemporary college students' ecological civilization education, and thus promotes the development of ecological civilization education in China.
\end{abstract}

Keywords-College students; Ecological civilization education; Problem; Training path

\section{INTRODUCTION}

The report of the 19th National Congress of the Communist Party of China pointed out: "Building ecological civilization is a millennium plan for the sustainable development of the Chinese nation. It is an important part of adhering to the harmonious coexistence of man and nature as the basic strategy for adhering to and developing socialism with Chinese characteristics in the new era. "The major goal of building a socialist modernization and strengthening the country in an allround way", [1] embodies the determination and confidence of the Party Central Committee for the construction of ecological civilization. As the guiding ideology of the theoretical level, ecological civilization education is indispensable to the construction of ecological civilization. As an important group and key force of the young generation, contemporary college students cultivate their ecological civilization education awareness and ecological civilization education responsibility, which is the urgent need for improvement in the current ideological and political education curriculum system. Therefore, the integration of ecological civilization education content into college courses, so that college students firmly establish the socialist ecological civilization concept, is of great significance to promoting China's ecological civilization construction and realizing the people's yearning for a better life.

\section{CURRENT STATUS OF ECOLOGICAL CIVILIZATION EDUCATION IN COLLEGES AND UNIVERSITIES}

Marx once said: "The spirit of an era is the spirit of youth, and the character of an era is the character represented by youth." As an important representative group of the younger generation, college students are the reserve power of the young backbone talents of the future, and they carry out ecological civilization. Education is both necessary and necessary. As the main front of the cultivation of college students' ecological civilization education, colleges and universities study the current situation of college ecological civilization education, which is of great significance to the cultivation of contemporary college students' ecological civilization education.

Objectively speaking, the current colleges and universities have made great achievements in carrying out ecological civilization education. The theory and practice of ecological civilization education have been continuously promoted, and the ecological civilization practice base has been completed, but it still needs to be improved compared with the emphasis on ecological civilization education in primary and secondary schools. . The fundamental reason for the lack of understanding of college students about ecological civilization education lies in the insufficient attention paid at the level of consciousness. Strictly speaking, there is no university that has cultivated ecological civilization education as a systematic discipline for all students. The focus of most college moral education work is on "An Introduction to Mao Zedong Thought and the Theory System of Socialism with Chinese Characteristics" and "Basic Marxism". Ideological and political theory courses such as "Introduction to Principles" and "Ideological and Moral Cultivation and Legal Basis". The focus of college moral education curriculum is to correctly handle interpersonal relationships, especially the relationship between people and society. It is only a simple part of people and nature, human and material world, let alone the theoretical teaching of ecological civilization education [2]. From the professional point of view, the systematic study of ecological civilization education is in the environmental science category. Many of the discourses and works on ecological civilization education are concentrated in the ecology major, and the targeted groups are also some science students. The ideological and political theory class did not absorb the knowledge about ecology into the curriculum system. The theory of ecological civilization education is inevitably floating on the surface, just like the rootless wood, the actual teaching effect will inevitably be greatly reduced. In addition, most of the full-time teachers in 
the ideological and political theory class are teachers of Marxist theory. Some teachers have limited research on the theory of ecological civilization education. The teaching of this theory in the course of teaching is not enough or not involved at all, and it is also the education of students for ecological civilization. An important reason for not paying enough attention. In short, the current colleges and universities do not pay enough attention to the education of ecological civilization, and the backward awareness of college students' ecological civilization education is not conducive to the exploration of the road of ecological civilization construction in China.

\section{THE PROBLEMS EXISTING IN COLLEGE STUDENTS' ECOLOGICAL CIVILIZATION EDUCATION}

\section{A. The professional knowledge of college teachers' ecological civilization is insufficient}

Throughout the education process of Chinese students, there are also subjects in nature and science in the primary and secondary schools. Since entering the university, with the refinement of selected majors and directions, most students are specialized in a certain subject, and the corresponding teaching position. The teachers are also specialized in one course. Even the same course can be taught for three or four years. For some teachers who are not widely involved, the relevant knowledge of ecological civilization education will not be systematically understood. When it comes to ecological civilization, it seems that everyone can come to the fore, but from a professional perspective, it is necessary to use books related to ecology. Therefore, from the coverage of the overall students, the teachers of the ideological and political theory class are the most suitable teachers to undertake the task of ecological civilization education. However, as the teacher of Marxist theory, the same problem exists above, and the ecological civilization education theory is taught as an important part of the ideological and political theory class. There are not many cases. In addition, the ideological and political theory prevailing in colleges and universities is not high in the classroom learning atmosphere, and the students' enthusiasm is not strong. The teachers usually finish a lesson according to the textbook and the swallowing date. The teaching effect of the ideological and political theory course has not achieved the desired effect. The teacher specializes in other subjects. Relevant knowledge, enthusiasm for integration into ideological and political theory courses is not high. The integration of ecological civilization education theory into the ideological and political theory class also requires more energy.

\section{B. The college students' awareness of their own ecological civilization is weak}

With the development of the new media era, the contemporary college students' understanding of the ecological environment is gradually strengthened. However, due to the influence of the new media fast-food communication, college students lack systematic awareness of the relevant concepts of ecological civilization education and lack opportunities for real practice. As a way for students to gain knowledge, there are relatively few other ways besides classrooms and networks. Especially with the development of the Internet, the spread of new media, all the information can be perceived without leaving the house, which also fosters the dependence of college students. In the Internet, relying on the sensory experience, away from the experience of outdoor experiential learning, ecological civilization education can only experience the "green water green hills" to understand the nature of ecological civilization education. It can be said that the current education mode and learning style have greatly influenced the cultivation of contemporary college students' awareness of ecological civilization education.

\section{The training capacity of ecological civilization education in colleges and universities is insufficient}

For the new era of colleges that impart knowledge and cultivate high-quality talents, it is an important task to cultivate college students in the new era who care about nature and protect the environment. When Xi Jinping answered questions from students at Nazarbayev University, he pointed out: "We need green mountains and green mountains, but also Jinshan Yinshan. We want green mountains and green mountains, not Jinshan Yinshan, and green mountains and green mountains are Jinshan Yinshan." [3] Training talents who attach importance to ecological civilization education is an important task of current colleges and universities. From the perspective of curriculum setting, the theory of ecological civilization education has not been incorporated into the ideological and political theory course. The related professional books and selected textbooks are not comprehensively configured, and students have less opportunities to understand ecological related knowledge. And the corresponding curriculum is equipped with insufficient teachers or professionalism. There are fewer opportunities for theoretical knowledge training in ecological civilization construction, and the relevant evaluation system is not perfect. From the perspective of practical and experiential teaching activities, colleges lack organization. The ability, the relevant practice bases are not closely linked, the practice forms are relatively simple, the participation of teachers and students is not high, and the significance of organizing practical activities is not reflected; [4] from the perspective of the environmental education of the university itself, the propaganda flows through the form. The propaganda effect is half the battle, the media propaganda is more than the current news hotspots, the environmental protection propaganda is more important than the heavy effect, and the propaganda activities are mostly staged, lacking co-ordination and coherence, and the actual ecological civilization education awareness is not strong.

\section{THE CULTIVATION PATH OF COLLEGE STUDENTS' ECOLOGICAL CIVILIZATION EDUCATION}

\section{A. At the level of education, teachers are the guides for ecological civilization education}

In the study of subjective education, scholars analyze the relationship between teachers and students in different periods, from "teacher subject theory", "student subject theory", "mutual subject matter theory" to later "teacher-led, studentoriented "[5] It is not difficult to find out that the role played by teachers in the teaching process is crucial. Therefore, it is essential to cultivate the awareness of college students' ecological civilization. First of all, teachers themselves must pay attention to the awareness of ecological civilization education, and learn the initiative of ecological civilization 
theory. Only on the basis of strong professional knowledge can we conduct interdisciplinary knowledge research and infiltrate the learned income into the ideological and political theory class. The teaching process. From meta-theory to social surface phenomena, students' awareness of the importance of ecological civilization education is deepened, and students' enthusiasm for active learning is mobilized, thus cultivating students' awareness of ecological civilization construction and responsibility. Secondly, the key to ecological civilization education is the relationship between man and nature. The basis of harmony between man and nature is firstly the understanding of the nature of nature. Interpretation of nature is not solely based on books or online video editing. It is necessary to cultivate college students' awareness of the protection of "green mountains and green mountains" and "clear water and pure land". [6] The key lies in direct contact with nature, so The construction of an ecological civilization education practice base is particularly important. Visiting ecological civilization demonstration counties and demonstration bases, teachers personally organizing students to participate in ecological civilization education and teaching activities are important opportunities for college students to reexamine the relationship between people and nature. Natural education is often more shocking. Of course, the most important thing is the demonstration role of the teacher. For the teacher, the influence of the teacher's own behavior on the students is subtle. The best way of education should be words and deeds.

\section{B. At the level of educational object, college students take the initiative to raise awareness of ecological civilization}

As an object of education, college students are not young people with insufficient physical and mental development. As a university student with the ability to distinguish between right and wrong, the reason for the lack of awareness of ecological civilization education should not be attributed to schools, teachers or parents. Improving the awareness of ecological civilization education and cultivating a sound personality literacy should be derived from the self-cognition of selfcognition and the need to improve the pace of social ecological civilization construction. As an independent individual, contemporary college students must correctly understand the determination and courage of the current state for the construction of ecological civilization, as well as the necessity of building ecological civilization and building "beautiful China" in China, and even the importance of understanding the ecological environment from the perspective of the community of human destiny [7]. Strengthening the understanding of ecological civilization education from the level of consciousness. College students must not only have a holistic view of development, but also be good at starting small and seeing big. College students should actively learn related books and electronic materials related to ecology, actively participate in various practical activities organized by the school, understand new initiatives and new developments in ecological civilization construction in the new era, closely follow the pace of ecological civilization construction, and consciously learn and understand. Other countries' policies on environmental protection, return to college classroom learning, and strive to promote the process of ecological civilization education theory construction.

\section{At the educational media level, colleges and universities improve the curriculum system of ecological civilization education}

As a key link in the great practice of ecological civilization construction, colleges and universities should make full use of the advantages of their own education platform, give full play to the important role of curriculum system setting in ecological civilization education, adjust the curriculum setting system and evaluation system of colleges and universities, and add ecological civilization to the student training plan. The content of education raises students' emphasis on ecological civilization education from the way of college students' training. Due to the different levels of ecological civilization education in different regions, the current colleges and universities pay different attention to the education of ecological civilization, and the contents infiltrated into the curriculum are also in different levels. Therefore, to improve the curriculum penetration of ecological civilization education theory, colleges and universities in all regions should unify the ideological and political theory curriculum and build an independent ecological civilization education theory curriculum system. At the same time, the whole education process of universities, middle and high schools, primary schools and pre-school education will be connected, and the education of ecological civilization will run through the whole process of students' growth and development, integrate and optimize educational resources, and fully mobilize the school's "Lide Tree People" in the practice of ecological civilization. Effect [8]. Taking the construction of ecological civilization education level as an important evaluation index of teaching level, and highlighting the important position of ecological civilization education from the levels of setting, management and evaluation [9].

\section{Promoting the environment of ecological civilization education at the level of education}

With the development of science and technology, the role of new media in publicity and education is becoming more and more important, and the environment of ecological civilization education is created. The network environment of colleges and universities is also essential. For new media propaganda, colleges and universities should pay attention to the construction of school information portals, Weibo, WeChat public number, BBS and other voice platforms, [10] actively use these publicity platforms to achieve the purpose of ecological civilization education, screening and pushing on the ecology. The information of civilized education uses the joint platform to carry out ecological civilization education activities improve the enthusiasm of college students to participate in activities, and cultivate the university's ecological civilization education literacy in a subtle way. From the perspective of the campus entity propaganda environment, it is necessary to use the landscape construction, the construction of civilized symbols, the propaganda column, and the propaganda manual to promote the construction of the theory of ecological civilization education. At the same time, colleges and universities can use the expert forum lectures and large-scale practical activities to put students in the atmosphere of ecological education, and hold publicity activities such as "ecological civilization into the campus" to carry out theoretical propaganda. Combine network propaganda with 
physical propaganda to better create an environment of ecological civilization education.

\section{CONCLUSION}

It is a long-term and arduous task to cultivate contemporary college students who have the literacy of ecological civilization education and assume responsibility for the construction of ecological civilization. Colleges and universities need to invest more material resources and energy, but it is far from enough to rely solely on the efforts of universities. Only the joint role of family, society and country can promote the development of China's ecological civilization education and realize the construction of "beautiful China".

\section{ACKNOWLEDGMENT}

About the author:

Zhang Hong, female, major in ideological and political education, graduate student of China Jiliang University.

\section{REFERENCES}

[1] Xi Jinping. Winning a comprehensive new well-off society and winning a great victory in socialism with Chinese characteristics in the new era [N]. People's Daily, 2017-10-18.

[2] $\mathrm{Hu}$ Tao, Director of the Party Committee of the Liaoning Provincial Department of Ecological Environment. Ecological civilization education urgently needs legislative protection [N]. China Environmental News, 2018-11-15 (003)

[3] Wang Hongping. Research on College Students' Ecological Civilization Education under the Background of "Internet + "[J]. Modern Communication, 2018(18): 104-105.

[4] Zhang Xiaojuan, Peng Yu, Zhong Xiaotong. Analysis of the Content of Ecological Civilization Education in China [J]. Academic Weekly, 2018 (29): 42-43.

[5] TANG Hua, LIN Aiju. The Realization Path of the Ecological Value of Ideological and Political Education in Colleges and Universities[J] Education Theory and Practice, 2018,38(24):32-34.

[6] Gong Ke. Taking the historical responsibility of ecological civilization education Cultivating a new generation of beautiful Chinese people $[\mathrm{J}]$. China Higher Education Research, 2018 (08): 1-5.

[7] Zhang Hongxia, Shao Nana. Exploring the Path of Integrating Ecological Civilization Education into College Students' Ideological and Political Education[J]. Marxism and Reality, 2018(04): 166-171.

[8] Zuo Xiaoshan. The Cultivation of Ecological Emotions Based on "Education in Education"--Innovative Practice of Off-campus Education in Youth Ecological Civilization[J].Environmental Education,2018(07):38-40.

[9] Huang Rusong. Analysis on the Cultivation Path of Contemporary College Students' Ecological Civilization View[J].Frontier,2016(09):18$20+30$.

[10] Li Guoliang, Zhou Xiangjun. The Value and Realization of Chinese Excellent Traditional Culture-Based on the Perspective of College Students' Ideological and Political Education[J]. Thought Education Research, 2018(09): 91-95. 